\author{
Ahieieva V., \\ Candidate of Philological Sciences, \\ Associate Professor of the Department of Translation \\ V.O. Sukhomlynsky National University of Mykolayiv
}

\title{
TYPES OF INTERFERENCE IN TRANSLATION
}

Summary. The article has been devoted to the problem of interference in translation. Interference in the process of translation plays an important role if we have deal with the English and the Ukrainian languages. The stated above languages are different in their structure and morphological characteristics. Thus, while translating from English into Ukrainian the translator faces peculiar difficulties. That is why such language phenomenon as language interference takes place. Interference according to the manner of influence is subdivided into hidden and not hidden. The classification of interference also depends on the linguistic nature. According to this, it can be phonetic, lexical, grammatical and orthographic. Phonetic interference is often connected with mistakes of phonological character. This type of interference is often called phonological. Lexical interference in translation is observed when we talk about intervention of word-stock of one language system into another one. Grammatical interference is connected with the word order, verbal and nominal sentences, the usage of the passive voice, subject-verb agreement, and the usage of prepositions. Orthographic interference is observed within transference of spelling rules from source language text into target language text.

Key words: process of translation, interference, phonetic interference, lexical interference, grammatical interference, orthographic interference.

Formulation of a research problem and its significance. Nowadays the problem of interference takes the leading position both in the English and the Ukrainian languages. Types of interference may be subdivided into several types. If we talk about the origin of interference, it may be external and internal. If we talk about the character of specific language skills transferred from mother tongue, than it may be direct and indirect. Types of interference are also classified according to the manner of influence and according to the linguistic nature. So, according to the manner of influence, we single out hidden and not hidden interference. And according to the linguistic nature it may be phonetic, lexical, grammatical and orthographic. The problem of interference in translation process is still a vital topic of researches as we still may observe disputable cases of interference classification in spite of the fact that the problem of interference is under the study of many scholars since $1980^{\mathrm{s}}$ [3]. The problem of interference is also important for the researches as it may influence both language and our specific language skills.

The goal and the specific tasks of the article. The main goal and the tasks of the article are dedicated to the problem of interference in cross cultural communication and the process of translation. The task of the article is to search the main types of interference that may be observed during the process of translation and to show the problematic areas of translation than can be influenced by different types of interference.
Analysis of the latest research into this problem proved that the problem of interference was studied by many scholars. Most of their works were dedicated to the aspect of interference influence on the process of translation, its peculiarities and significance are detected. Among the most famous scientists we may easily single out V. Alimov, E. Buzharovska, E. Haugen, L. Kovylina, W. Weinreich and others. Their researches are devoted to studying different aspects of translation, changes made under the influence of one language on another one. It's a well-known fact that while translating we have to take into consideration lexical and grammatical peculiarities of the source and the target languages that may influence the whole process of translation. It is proved that any translator faces difficulties in his/her work as his/her task is not only to convey the information but to convey it appropriately. In cross-cultural communication where the process of interference is widely observed one of the main problems is that some languages are full of cultural terms and expressions (which are also called cultural specific). The cultural specific expressions are quite difficult to translate. This happens because the cultural context is too vague as it represents the world view and the world perception of a society [3].

Statement regarding the basic material of the research. Communication as a general phenomenon is the process of the message transmission consisting of the three parts - the sender, the message and the recipient. In other words, it is the process of exchanging ideas, information etc. between two or more people. Communication has always been an important need of all societies and it is still an integral part of our life. It may occur between people of the same culture (and language) and of different cultures (and languages). The latter means the transmission of information through cross-cultural communication and the difficulties we face in it. It's not only cultural specific expressions (as it was mentioned above) but also facial expressions, gestures with universal and different meaning in different cultures etc.

As for the role of translation in the process of communication, it performs several functions. It is the function of breaking misunderstanding among representatives of different cultures. Then it is the communicative function as a translation process is the transmission of information first of all. And the third function is the comparison and the correlation of language units.

As for the interference as the language phenomenon it is often regarded as negative.

V. Alimov in his work "Interference and translation" points out the following types of interference: phonetic interference, orthographic interference, grammatical interference, lexical interference, semantic interference, stylistic interference, and interference within language. Phonetic interference is observed when we make mistakes of phonological character where we change sound form and meaning, and these mistakes may lead to disturb- 
ing communication act. According to this phonetic interference is sometimes called phonological interference. The examples of phonetic interference may be observed in such words as "childhood" or "development" where we may find issues connected with the stress.

Graphic or orthographic interference happens in writing where we make transference of spelling rules from source language text into target language text. This causes orthographic mistakes and graphic incongruity. For example, personal pronoun "I" in the English language is written with the help of a capital letter, and this may cause a mistake when translator in the Ukrainian language writes《я» also with the help of a capital letter.

The main peculiarity of the phonetic interference is that it concerns the manner the listener or the speaker gets and produces or reproduces the sounds of one language in terms of another. Phonetic interference may occur due to four factors. The first factor is properly phonic. This includes differences in the stocks of phonemes of the languages in contact, in the componential analysis, and in the distributional patterns of their phonemes. The second factor is extra-phonic factors. This type of factor is aimed to avoid a particularly undesirable homophony. The third factor is extra-linguistic factor. It is connected with the motivations to achieve intelligible, acceptable or native-like speech present in a definite speech situation or in the general socio-cultural setting where the language contact takes place. The fourth factor is connected with erratic cases of phonetic interference which is similar to the unaccountable kind of slips of the tongue that an unilingual speaker makes.

Orthographic interference is based on the tendency to extension of internationality in modern language parallels of the European languages. The above stated tendency shows that new borrowings (barbarisms and foreignisms) are adopted into language without taking into consideration phonetic or orthographic rules of the target language. And in this case we have the full right to talk about extra linguistic cases of preserving foreign sounds and forms [4]. Some scholars denote that orthographic interference may be combined with graphic interference as the both: 1) may be singled out in writing; 2) transfer rules of writing from source language text into target language text; 3 ) cause spelling mistakes.

The phonetic interference is shown in change of the place of an accent in some foreign words under the influence of the native language, for example: magazine, industry, collegue; and also in pronunciation of letters not pronounced in English: whistle, sword. Also cases of the so-called wrong accent of words are widespread in the English language. It concerns those words where the accent falls on the first syllable if it is nouns and on the second syllable if it is verbs: suspect - suspect. The phonetic interference takes place when distinctive sign, characteristic of the phonetic system of one language, is absent in another one. As for the main types of a phonetic interference, they are: wrong accent; omission of sounds which do not exist in Ukrainian; pronunciation of sounds which by rules of the English phonetics have to fall; wrong reading combinations of letters; others altered manifestations in language phonetics which not only distort the correct sounding of language, but also add over time to its lexemes of uncharacteristic sounds, has result of formation of words with negative impact on purity of language and its originality.

Lexical interference is observed when we define intervention of word-stock of one language system into another one, and it may lead to literalisms. As an example of lexical interference we may define the word "magazine" which is rendered into Ukrainian as «журнал» but not as «газета».

Semantic interference is defined while intervention of elements of one language system into another one on the semantic level. As an example we can give the following sentence «Забронюйте, будь ласка, номер у готелі» where a translator may use the word "number" instead of "room".

Morphological interference is observed when we find peculiar grammatical forms and constructions. For example, when we use not appropriate prepositions in source language and target language texts. It happens due to the influence of mother tongue and morphological differences in languages under comparison. Another example of morphological interference is the usage of verbal phrases of the English language consisting of more than two words and their equivalents in Ukrainian consisting of only one word. And of course this may influence the process of translation as a translator may use a wrong word or a phrase.

And finally stylistic interference may be observed while influence of a style of one language on a style of another language. That's the case when a translator uses jargonisms or slang words to render lexical units belonging to the neutral layer of word-stock.

One of the main manifestations of a spelling interference in linguistics and in the translation is transliteration which definitely presents difficulties for the translator, especially if he / she deals with proper names. Therefore, the term "transliteration" designates the transmission medium of foreign-language words borrowed on the basis of graphic structure of original language on the graphic system of target language text. In translation several types of transliteration allocate. They are: 1) a strict transliteration which provides consecutive replacement of one sign only with one sign of other letter; 2) weakened, consisting in replacement only of some signs; 3 ) expanded which characteristic is in representation of the corresponding connections of signs in the special way in other system of the latter.

Usage of transliteration in translation process, especially if we talk about names, has certain specifics. The transliteration differs from a practical transcription in the simplicity and a possibility of introduction of additional signs. The transliteration is often applied by drawing up bibliographic indexes and at the organization of catalogs, for example, when it is necessary to collect in one place of the catalog the description of all works of the domestic author by foreign languages.

The effects of lexical interference depend on the fact whether the speaker monolingual or bilingual is. In the outright transfer of morphemes the borrowed term will be clearly understood by bilinguals but misunderstood by monolinguals. Lexical interference, in general, may be characterized as the occurrence of deviations from generally accepted monolingual sign-content norms of either of the languages in contact.

In the process of translation we may also observe the grammatical interference (if we talk about the structure of the languages and their morphological peculiarities). The notion of grammatical interference includes such elements as word order, verbal and nominal sentences, the usage of the passive voice, subject-verb agreement, and the usage of prepositions. Of course, all the above mentioned elements of grammatical interference cause peculiar problems in the process of translation as the English and the Ukrainian languages, for example, are quite different in their structure and the morphological characteristics. 
All the above mentioned types of interference, as well as the structural peculiarities of languages, have to be overcome in the process of translation. To do this, translators often use the so-called strategies of translation. Among them we may easily single out: generalization, the strategy of translation by a more specific term, the strategy of translation by cultural substitution, translation by paraphrase and the strategy of translation by omission. Each of them has its own advantages and disadvantages. The strategy of generalization presupposes the usage of a word or even the whole concept with a more general meaning instead of a more specific word or the concept. The strategy of translation by a more specific term presupposes the search of more general word. The strategy of translation by cultural substitution involves substitution of a culture specific item or expression when we replace a culture specific item in the source language text by a target item with the similar concept in target culture to provide a similar impact on the target language reader. The strategy of usage of loan words is used in dealing with culture-specific items when we have a deal with newly formed or newly introduced concepts followed with footnotes or explanations. The strategy of translation by paraphrase in cross-cultural communication is used if the word (or a concept) is localized in the target language. The strategy of translation by omission in cross-cultural communication is observed in the case of items possessing extreme difficulties in translation.

Conclusions. Interference as a language phenomenon may be of several types according to the manner of influence and according to the linguistic nature. Modern scholars single out the following types of interference in translation: phonetic, lexical, grammatical and orthographic. Phonetic interference is observed when we make mistakes of phonological character where we change the sound form and the meaning, and these mistakes may lead to disturbing communication act. Lexical interference is observed when we define intervention of word-stock of one language system into another one, and it may lead to literalisms. Grammatical interference in the meaning structure of the languages and their morphological peculiarities includes such elements as word order, verbal and nominal sentences, the usage of the passive voice, subject-verb agreement, and the usage of prepositions (which cause peculiar difficulties in the process of translation). Orthographic interference presupposes the usage of extra linguistic cases of preserving foreign sounds and forms.

Within the above mentioned types of interference in translation scholars also define such types of interference as semantic, morphological and stylistic. Semantic interference is observed in the intervention of elements of one language system into another one on the semantic level. Morphological type of interference is characterized as the usage of peculiar grammatical forms and constructions, not appropriate prepositions in source language and target language texts. Stylistic interference is the type of interference observed while influence of a style of one language on a style of another language or the breaking of norms of stylistics.

To overcome the difficulties in translation caused by the structural peculiarities of languages (especially if we talk about the English and the Ukrainian languages) translators often use specific translation strategies. They help to overcome the structural differ- entiation of the languages. To these strategies belong such methods as: generalization, the strategy of translation by a more specific term, the strategy of translation by cultural substitution, translation by paraphrase and the strategy of translation by omission.

\section{References:}

1. Алимов В. Интерференция в переводе. Москва : Эдиториал УPCC, 2005. $232 \mathrm{c}$.

2. Карабан В. Попередження інтерференції мови оригіналу в перекладі: вибрані граматичні та лексичні проблеми перекладу з української мови на англійську. Вінниця : Нова книга, 2003. 208 с.

3. Семчинський С. Семантична інтерференція мов. Київ : Вища школа, $1974.256 \mathrm{c}$.

4. Фінкель О. Забутий теоретик українського перекладознавства / за ред. Л. Черноватого, В. Карабана. Вінниця : Нова книга, 2007. $438 \mathrm{c}$.

5. Baker M. In other Words. London : Routledge, 1992. 128 p.

6. Bartell M. Internationalization of universities: a university culturebased framework. London : Higher Education, 2003. $150 \mathrm{p}$.

7. Bell R. Translation and Translating. London : Longman, 1991. 248 p.

8. Brown H. Douglas. Principles of language learning and teaching. New York : Longman, 2000. 186 p.

9. Robinson-Stuart Gail, Nicon Honorine. Second culture acquisition: Ethnography in the foreign language classroom. Modern Language Journal. 1996. Vol. 8. P. 430-432.

\section{Агєєва В. О. Типи інтерференції в перекладі}

Анотація. Статтю присвячено проблемі інтерференції у процесі перекладу. Інтерференція як мовне явище виникає у процесі перекладу та відіграє важливу роль, якщо ми маємо справу 3 англійською й українською мовами (особливо коли перекладаємо тексти цими мовами). Вищезазначені мови різні за своєю структурою, морфологічними ознаками та характеристиками. У процесі перекладу текстів 3 англійської мови українською та 3 української мови англійською перекладач стикається 3 днякими труднощами. Саме через цей факт ми говоримо про таке мовне явище, як інтерференція. Дослідники виділяють декілька типів інтерференції, наприклад, за способом впливу на мову, вона може бути прихована та неприхована. Класифікація типів інтерференції також залежить від певного набору лінгвістичних показників. Залежно від цього інтерференцію поділяють на декілька типів: фонетичну, лексичну, граматичну й орфографічну. Фонетичний тип інтерференції зазвичай пов'язують із помилками фонологічного характеру. Саме тому цей тип інтерференції часто називають фонологічною. Лексичний тип інтерференції в перекладі спостерігається за умови проникнення словникового складу однієї мовної системи у словниковий склад іншої мовної системи. Граматична інтерференція у процесі перекладу спостерігається в рпзі порушення порядку слів у реченні, за використання пасивного стану дієслова (поширений в англійській мові, проте відсутній в українській мові), використання або опущення займенників тощо. У разі перенесення правил письма 3 однієї мови в іншу ми говоримо про наявність орфографічної інтерференції в перекладі.

Ключові слова: процес перекладу, інтерференція, фонетична інтерференція, лексична інтерференція, граматична інтерференція, орфографічна інтерференція. 